\title{
EFFECT OF ROTERY PLOW AND PRECISION LAND LEVELING ON FABA BEAN RESPONSE TO ORGANIC FERTILIZATION
}

\author{
Bahnas, O. T.* and M. Y. Bondok ${ }^{* *}$
}

\begin{abstract}
This study was carried out to identify the effect of rotary plow and precision land leveling on faba bean response to organic fertilization using the incorporated rice straw into the soil. The experiment was designed statistically as a split plots with three replicates. The main plots involved the rotary plowing treatment levels i.e. rotary plow as a minimum tillage, rotary plow after chisel plow(one pass) and rotary plow after chisel plow(two passes). The sub plots were located for the precision land leveling slope treatment levels i.e. 0.01, 0.02 and 0.03\%, comparing with chisel plow(two passes) followed by traditional land leveling under bereaved of rice straw application. The rotary plow after chisel plow 1 pass followed by $0.02 \%$ precision land leveling slope under rice straw application accomplished more desirable soil characteristics, required the lower total applied irrigation water amount, produced higher seed yield and terminated higher water use efficiency.
\end{abstract}

\section{INTRODUCTION}

Tn Egypt, the annual faba bean cultivated area is about 42,522 ha which produced about 148,721 ton seeds (Ministry of Agricultural and Land Reclamation, 2013). Faba bean constitutes a major part of the diet due to the richness in seed protein content. It uses as a vegetable either green, dried fresh or canned, as well as, using secondary product as animal feeding. It plays an important role in maintaining soil productivity due to fixing atmospheric nitrogen according to the symbiotic relation with rhizobium through root nodules (AbouAmer et al., 2014).

Fertilization is considered as an efficient factor in faba bean production (Abd El-Aziz (2008) and Abou-Amer et al., 2014). The excessive and continuous chemical fertilizers application occurs accumulated side

\footnotetext{
" Head of Researcher at Agric. Eng. Res. Inst. (AEnRI), Agric. Res. Center.

** Emeritus Head of Researchers at Agric. Eng. Res. Inst. (AenRI) Agric. Res. Center.
} 
effects on the human and the animal health and the environment and maximizes the agricultural production costs (Savci, 2012). The egyptian agricultural policy directed a great attention to minimize chemical fertilizers application. There is recent attention towards utilization rice straw as an organic soil conditioner (Khider, 2004 and Ali, 2011). Abdelhameed et al. (2004) found that the composted rice straw significantly enhanced faba bean growth and increased crop yield.

During rice harvest, the combine harvester distributes straw upon the soil surface without chopping. The long straw pieces may swing and breakdown during the next crop soil preparation. There are available options to farmers for rice straw management including burning, baling and incorporation and surface retention. Due to the high cost of rice straw assembling and transporting, the farmers choose the easy, inexpensive and rapid method through the uncontrolled burning that disposition it and save enough time to prepare the seedbed for the next crops, regardless of environmental pollution (El-Gendy, et al., 2009). The rotary plow is an appropriate implement for $\mathrm{r}$ ice straw incorporation (Abdel-Galil, 2007 and Rusu et al., 2011). It imparts rotation to successive bites of the soil. Then, the chopped straw pieces fall between soil bites and mix with the soil particles, enhancing straw decomposition rate by improving contact between soil particles and straw pieces, achieving appropriate soil conditions (Ji et al., 2012).

Faba bean responds well to irrigation as plants are not particularly susceptible to water logging. Hence, controlled irrigation is essential to produce faba bean high crop yield and quality (Hegaba et al., 2014). Faba bean is sensitive to both over and under irrigation. Beginning of the flowering period is most sensitive to water shortage. Soil water depletion in the root zone during this period should not exceed $25 \%$. Water shortage just prior and during early flowering reduces the number of fruits (ElGendy et al., 2001 and Samiha et al., 2010). So, it is an important issue to depend on the precision land leveling as an efficient and rationalized method to manage the available water (El-Khatib et al., 2014). Meanwhile, rice straw incorporation increases soil moisture accumulation, resulting in the increased soil water- holding capacity (Lentz and Bjorneberg, 2003 and Bescansa et al., 2006). Bahnas and 
Bondok (2010) indicated that the precision land leveling increased faba bean response to application of the composted rice straw. Hence, the present work aimed to assess rotary plowing and precision land leveling under organic fertilization using rice straw on faba bean crop yield.

\section{MATERIAL AND METHODS}

Experimental site and soil characteristics:

During October 2013 to end of April 2014, a field experiment of 0.36 ha $(105$ x $60 \mathrm{~m})$ was established at Kalabsho Region, El-Dakhlia Governorate, Egypt that is located at 31.409408 latitude and 31.478470 longitude with an altitude of 1550 masl which has an average annual rainfall of $175.00 \mathrm{~mm}$, wheres the preseeding crop was rice which was harvested using a general purposes combine harvester. As cited by ElSerafy and El-Ghamry (2006), Table (1) shows the soil mechanical analysis and the soil texture classification. As pointed out by El-Serafy and El-Ghamry (2006) and Garcia (1978), Table 2 presents some soil characteristics. According the procedure of El-Serafy and El-Ghamry (2006), some rice straw characteristics are shown in table (3). According to Mc Clung et al. (1985), Fig. 1 demonstrates the experimental site survey which was measured in terms of surveying grid.

Table 1: Soil mechanical analysis of the experimental site.

\begin{tabular}{|c|c|c|c|c|l|}
\hline \multicolumn{3}{|c|}{ Sand, \% } & \multirow{2}{*}{ Silt, \% } & Clay, \% & $\begin{array}{l}\text { Soil texture } \\
\text { class }\end{array}$ \\
\hline Coarse, \% & Fine, \% & Total, \% & 14.85 & 17.11 & Sandy \\
\hline 64.41 & 3.63 & 68.04 & 14.85 & \\
\hline
\end{tabular}

Table 2: Some soil characteristics of the experimental site.

\begin{tabular}{|c|c|c|c|c|c|c|c|}
\hline \multirow{2}{*}{$\begin{array}{l}\text { Bulk } \\
\text { density, } \\
\mathrm{g} / \mathrm{cm}^{3}\end{array}$} & \multirow{2}{*}{$\begin{array}{c}\mathrm{pH}, \\
1: 2.5 \\
\text { (susp.) }\end{array}$} & \multicolumn{3}{|c|}{$\begin{array}{c}\text { Available nutrients, } \\
\text { ppm }\end{array}$} & \multirow{2}{*}{$\begin{array}{c}\text { Field } \\
\text { capacity, } \\
\mathrm{Wt} / \mathrm{wt} \%\end{array}$} & \multirow{2}{*}{$\begin{array}{l}\text { Wilting } \\
\text { point, } \\
\text { Wt/wt } \%\end{array}$} & \multirow[t]{2}{*}{$\begin{array}{l}\text { Infiltration } \\
\text { rate, } \mathrm{mm} / \mathrm{h}\end{array}$} \\
\hline & & $\mathrm{N}$ & $\mathrm{P}$ & $\mathrm{K}$ & & & \\
\hline 1.55 & 7.30 & 21.41 & 10.71 & 271.40 & 17.01 & 6.90 & 45 \\
\hline
\end{tabular}

Table 3: Some rice straw characteristics.

\begin{tabular}{|c|c|c|c|c|c|}
\hline $\begin{array}{c}\text { Moisture content, } \\
\% \text { (d. b.) }\end{array}$ & $\begin{array}{c}\text { Ash, } \\
\%\end{array}$ & $\begin{array}{c}\text { Organic matter, } \\
\%\end{array}$ & $\begin{array}{c}\text { Organic carbon, } \\
\%\end{array}$ & $\begin{array}{c}\text { Total N, } \\
\%\end{array}$ & $\begin{array}{c}\mathrm{C} / \mathrm{N} \\
\text { ratio }\end{array}$ \\
\hline 9.00 & 17.79 & 75.21 & 43.46 & 0.482 & 90.16 \\
\hline
\end{tabular}




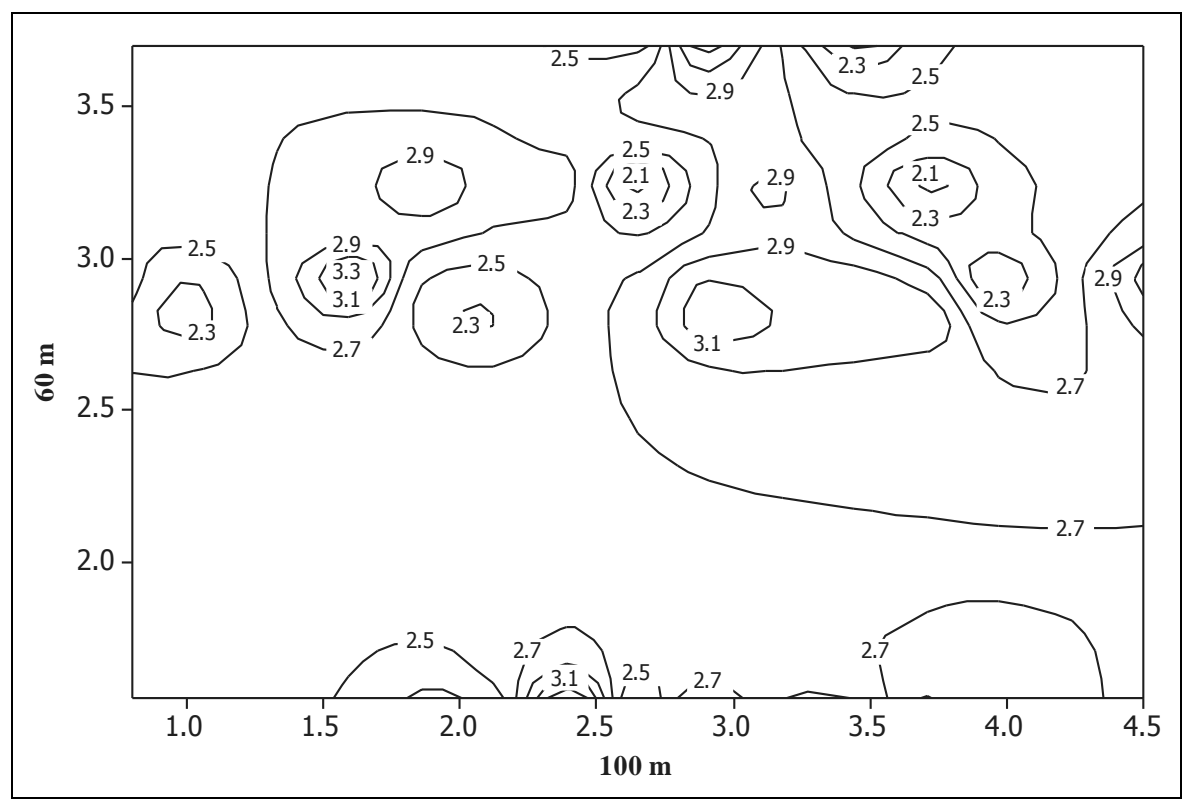

Fig. 1: Schematic diagram of the experimental site topography.

Treatments and statistical design:

During the experiment, the following treatments were tested:

1. Rotary plowing which included levels of rotary plow as a minimum tillage, rotary plow after chisel plow(1 pass) and rotary plow after chisel plow(2 passes).

2. Precision land leveling slope which included levels of $0.01,0.02$ and $0.03 \%$.

These treatments were compared with chisel plow(two passes) followed by traditional land leveling $0.01 \%$ slope and accompanied with bereaved of rice straw application (control). The experiment was established as a split plots statistically design with three replications. The main plots involved the rotary plowing treatment levels and the sub plots included the precision land leveling slope treatment levels.

Agricultural practices:

\section{Seed bed preparation:}

The seed bed was prepared as the previous treatments. The soil was tilled using a 7 shares chisel plough. Rice straw was chopped and incorporated into soil using a rotary plow with $24 \mathrm{~L}$ - shape blades. The traditional land leveling was carried out using a mounted hydraulic scraper of $1.26 \mathrm{~m}^{3}$ 
capacity $(0.60 \times 3.00 \times 070 \mathrm{~m})$. For precision land leveling, the scraper was accompanied with a laser control equipment that consists of transmitter (Spectra-physics 1145 laser plane), control box (CB2MTD), receiver mast, receiver unit and telescoping grade rod (1084 English).

\section{Planting:}

A 4 rows pneumatic planter was used to plant the selected seeds of Giza 3 faba bean variety at row spacing of $0.60 \mathrm{~m}$ with $0.20 \mathrm{~m}$ hill spacing at the same row.

The chisel plough, the rotary plough, the hydraulic scraper and the planter were operated using a $2 \mathrm{WD}$ tractor of $60 \mathrm{~kW}$ power. The precision land leveling unit was operated using a $4 \mathrm{WD}$ tractor of $90 \mathrm{~kW}$ power.

\section{Irrigation:}

The border surface irrigation system was applied using an electric archimedean screw of $252 \mathrm{~m}^{3} / \mathrm{h}$ discharge. The irrigation was scheduled as 4,3 and 2 irrigations with intervals of 12,14 and 16 days to achieve 50,60 and $70 \%$ of the available water during flowering, bud setting and maturity growing stages, respectively.

The other practices were done uniformly for all treatments according to the recommendations of Ministry of Agriculture and Land Reclamation (2005).

\section{Measurements:}

\section{Soil characteristics:}

At harvest, soil mean weight diameter, soil bulk density, soil infiltration rate and soil available macronutrients concentration were determined according to Kepner, et al. (1982), ASAE (1992), Garcia (1978) and Hesse (1971), respectively.

Total irrigation water amount:

The total irrigation water amount (TIW) is determined as follows:

$$
T I W=\frac{L R+C R}{\eta A} m^{3} / \mathrm{fed}
$$

Where: $L R$ is leaching requirements, $\mathrm{m}^{3} / \mathrm{fed}$.

$C R$ is crop water requirements, $\mathrm{m}^{3} / \mathrm{fed}$.

$\eta$ is irrigation system efficiency, $\%$. 
$A$ is irrigated area, fed.

$L R$ is estimated as outlined by Doorenbos and Prutt (1977) as follows:

$L R=\frac{E C i}{E C_{d}}$

Where: $E C_{i}$ is irrigation water electrical conductivity, $\mathrm{dS} / \mathrm{m}$.

$E C_{d}$ is drainage water electrical conductivity, $\mathrm{dS} / \mathrm{m}$.

The net crop water requirements and the irrigation interval (II) are calculated as cited by FAO (1979) and Israelson and Hansen (1962) as follows:

$W H C=(F C-P W P) p_{\mathrm{b}} \cdot \mathrm{d} .10 \mathrm{~mm}$

$\operatorname{Max} . C R=\frac{M A D \cdot W H C}{100} \mathrm{~mm}$

$\operatorname{Max} . C R=\frac{M a x \cdot g \cdot w \cdot r}{\eta} m m$

$I=\frac{\text { Max.CR }}{\text { Etcrop }}$ day

$\mathrm{Et}=\mathrm{Et}_{0} \times \mathrm{kcmm} /$ day

Where: $W H C$ is soil water holding capacity, $\mathrm{mm}$.

$F C$ is soil field capacity, $\%$.

$P W P$ is soil permanent wilting point, $\%$.

$P_{b}$ is soil bulk density, $\mathrm{g} / \mathrm{cm}^{3}$.

$D \quad$ is effective root zone depth, $\mathrm{m}$.

$M A D$ is management allowable deficit, $\mathrm{mm} / \mathrm{m}$.

Max. g.w.r is maximum gross water requirements, $\mathrm{mm}$.

Et is net crop water requirements, $\mathrm{mm}$.

$\mathrm{EtO}$ is potential evapotranspiration, $\mathrm{mm} /$ day.

$K c$ is crop factor.

EtO was calculated according to the data recorded by KafrSaad weather station, Domitt Governorate, Egypt which is affiliated to the Central Laboratory for Agricultural Climate, Agricultural Center Res., Ministry of Agriculture and Land Reclamation, Egypt.

According to James (1988), the irrigation water amount is determined using a rectangular shape crested weir as follows:

$Q=k . c d . A \sqrt{H} \quad \mathrm{~L} / \mathrm{s}$ 
Where: $Q$ is orifice discharge, $\mathrm{L} / \mathrm{s}$

$k$ is discharge coefficient.

$c d$ is constant unit.

$A$ is orifice area, $\mathrm{m}^{2}$.

$H$ is effective water head over the orifice center, $\mathrm{m}$.

Land leveling accuracy:

At harvest, land leveling accuracy is determined according to Mc Clung et al.. (1985) as follows:

a. Soil topography:

It is studied in terms of surveying grid and standard deviation.

b. Land leveling index (p.l.i.):

$$
\text { p.l.i. }=\frac{\sum C+\sum F}{N} \mathrm{~m}
$$

Where: $C$ is cut required at grid point, $\mathrm{m}$.

$F$ is fill required at grid point, $\mathrm{m}$.

$N$ is number of points.

\section{Faba bean seed yield:}

At harvest, for each experimental unit, an area of one $\mathrm{m}^{2}$ was taken randomly to determine the faba bean seed yield. Then, it was calculated on basis of $14 \%$ moisture content $(\mathrm{d} \mathrm{b})$.

Water use efficiency (WUE):

$$
W U E=\frac{\text { grain y ield, } \mathrm{kg} / \mathrm{fed} .}{\text { appllied irrigation water amount }, \mathrm{m}^{3} / \mathrm{fed} .} \mathrm{kg} / \mathrm{m}^{3}
$$

Statistical Analysis:

SAS computer software package version 9.10 is used to employ the analysis of variance and the LSD tests for faba bean seed yield data. Regression and Correlation Analysis:

Microsoft Excel 2013 computer software is used to carry out the simple regression and correlation analysis to represent the relation between faba bean seed yield and precision land leveling slope under different of rotary plowingtreatment levels. 


\section{RESULTS AND DISCUSION}

\section{Soil Characteristics:}

Through Figures (2) to (7), data show that the rotary plow after chisel plow1 pass followed by $0.02 \%$ precision land leveling slope achieved the moderate soil mean weight diameter of $25 \mathrm{~mm}$, the lower soil bulk density value of $1.28 \mathrm{~g} / \mathrm{m}^{3}$, the lower soil infiltration rate value of 20 $\mathrm{mm} / \mathrm{h}$ and the higher concentration of soil macronutrients values of 24,17 and $311 \mathrm{ppm}$ for N, P and $\mathrm{K}$, respectively. This result may be explained that the chisel plow1 pass disturbs the soil, achieving the crumbled clods that tend to be loose and free to move with the beating action of the rotary plow blades, resulting in moderate size of soil particles. Whilst, the 2nd pass of the chisel plow increases the disturbed soil, minimizing the beating action of the rotary plough, creating larger soil particles. Whilst, using the rotary plow as a minimum tillage achieved the lower values of soil mean weight diameter. It could be illustrated that the untilled soil is objected to the subsequent beating action of the shares, leading to higher kinetic energy charged to the crumbled clods, causing higher impact action between the clods together, resulting in finer soil particles.

The figures declare that the precision land leveling achieved the soil particles of smaller mean weight diameter, lower values of soil bulk density, lower values of soil infiltration rate and more amount of the available soil macronutrients concentration than that were obtained using the traditional leveling by 25, 4, 11 and 105, 121 and 109\%, respectively. This finding may be explained that the precision land leveling accomplished fine soil particles, which having a negligible electromagnetic charge, increasing the soil free pore spaces per unit volume, resulting in lower soil bulk density. Consequently, the irrigation water streams, detaches soil particles from the surface and pushes fine particles into surface pores, creating smaller pores that offer greater resistance to gravity, where they can impede the infiltration process. Meanwhile, the finer soil particles of greater specific surface area may release more amounts of the available soil macronutrients.

The figures reveal that rice straw application improved the soil characteristics, comparing with the bereaved of rice straw application. It is due to decomposition of the retained rice straw in the voids of soil 
particles and sticking one to another that increased the free pore spaces per soil volume unit.

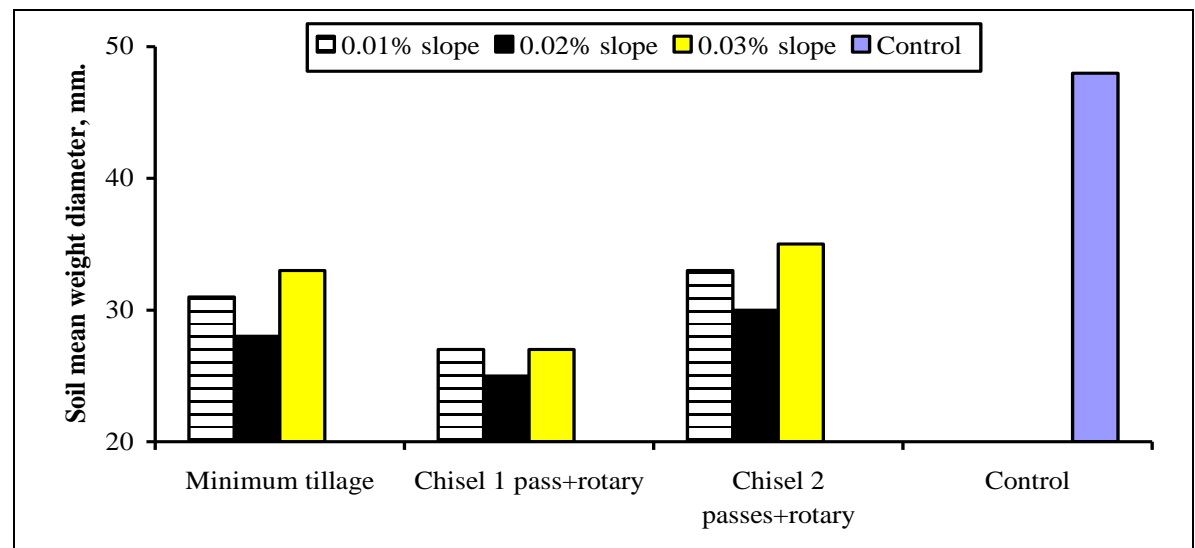

Fig. (2): Effect of rotary plow on soil mean weight diameter under different precision land leveling slope levels.

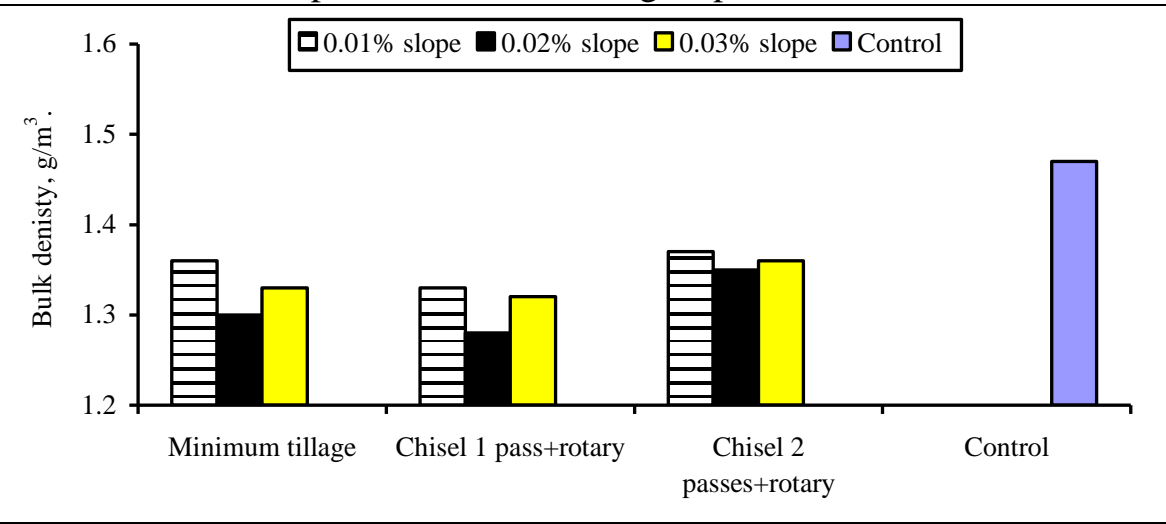

Fig. (3): Effect of rotary plow on soil bulk density under different precision land leveling slope levels.

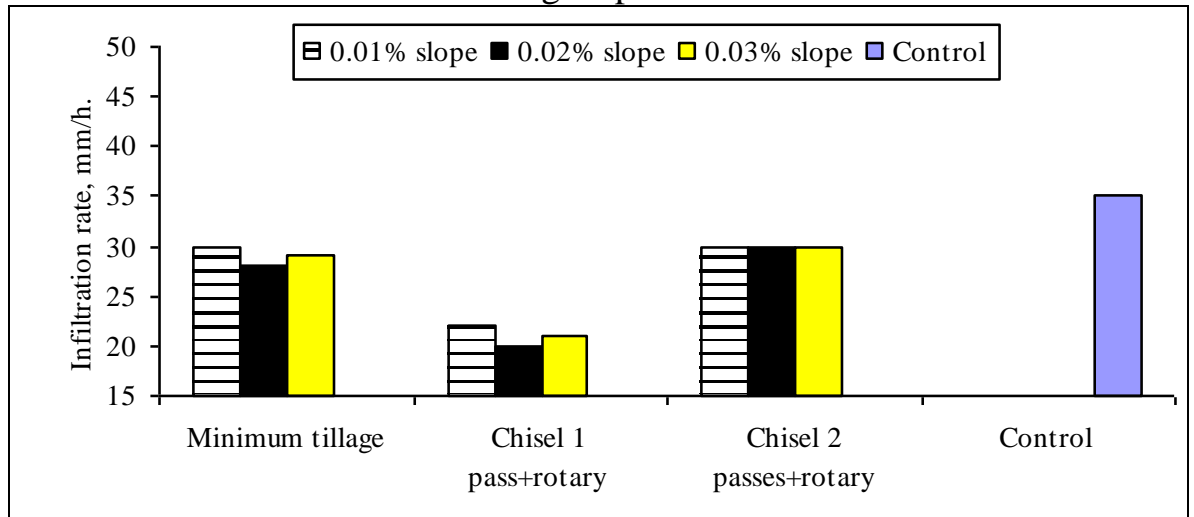

Fig. (4): Effect of rotary plow on soil infiltration rate under different precision land leveling slope levels. 


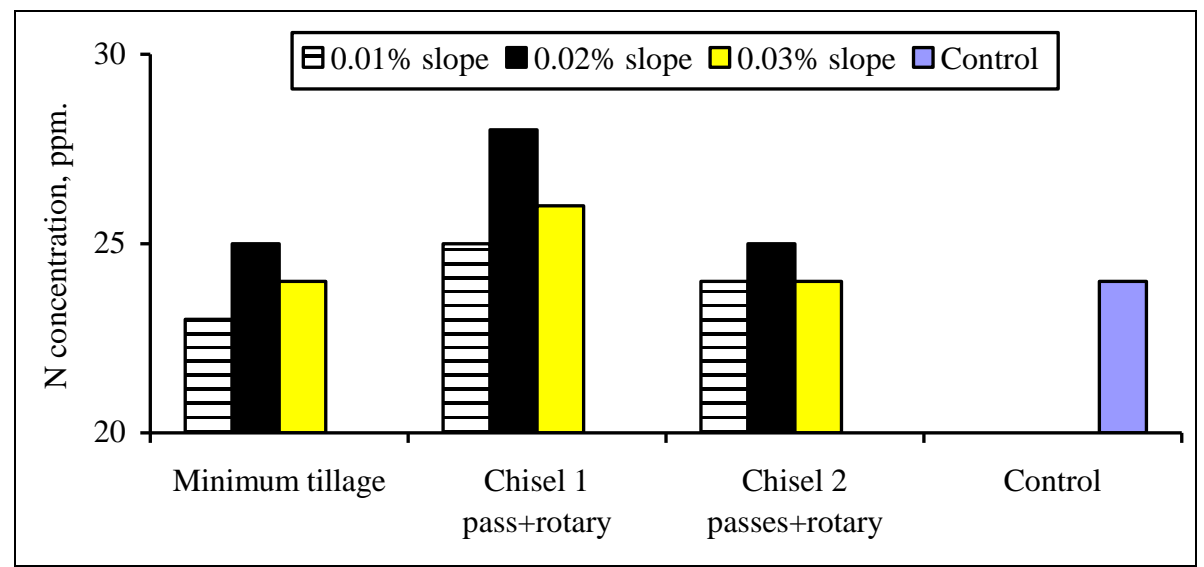

Fig. (5): Effect of rotary plow on available soil $\mathrm{N}$ concentration under different precision land leveling slope levels.

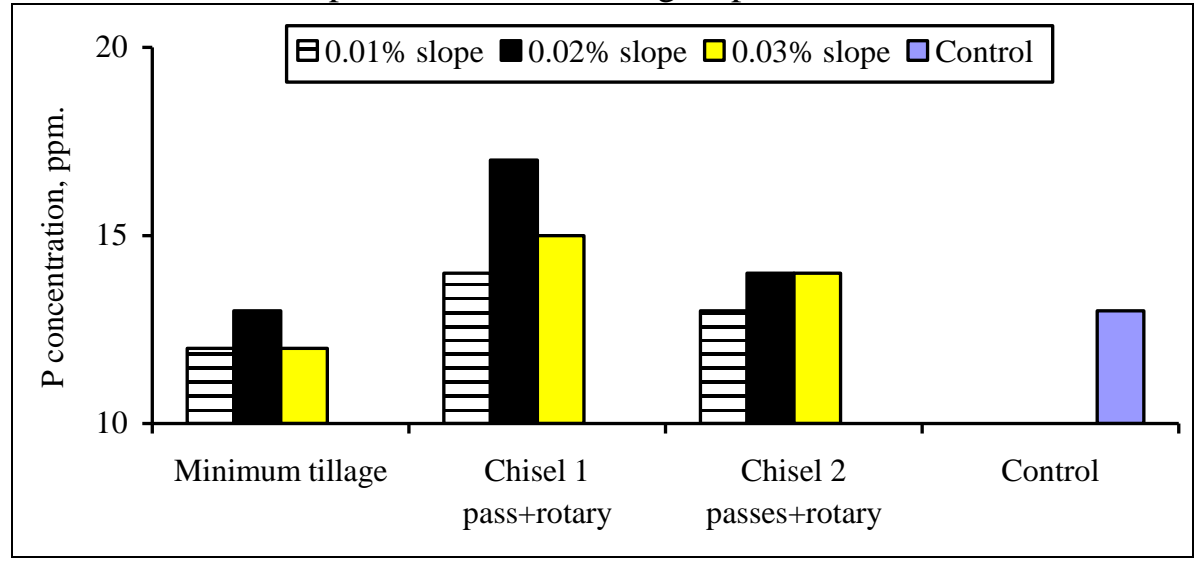

Fig. (6): Effect of rotary plow on available soil P concentration under different precision land leveling slope levels.

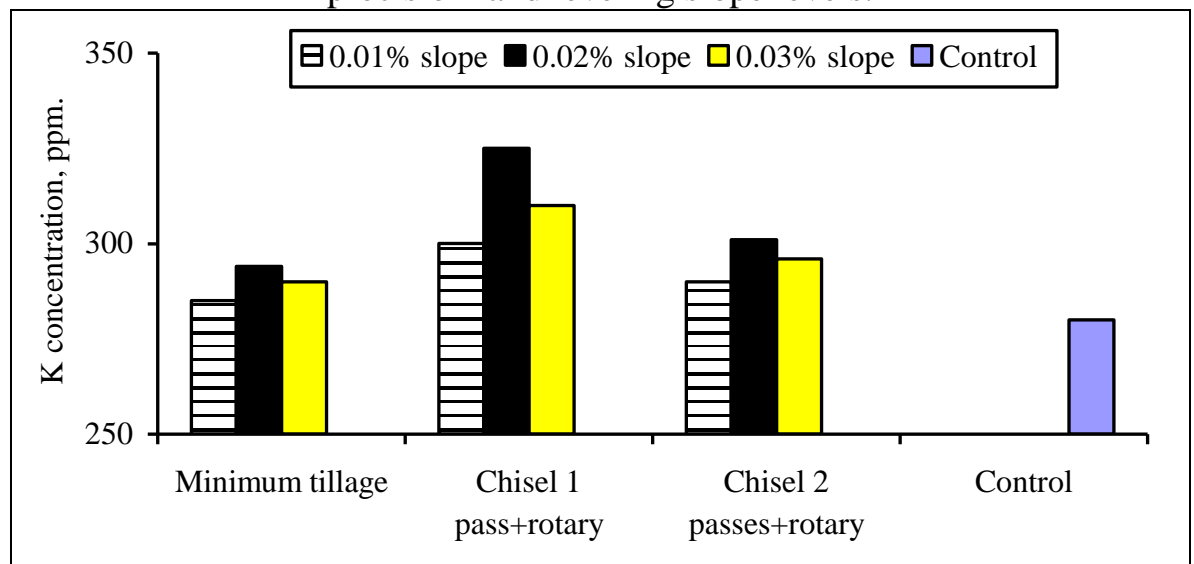

Fig. (7): Effect of rotary plow on available soil K concentration under different precision land leveling slope levels. 
Applied Irrigation Water amount:

Figure (8) transposes that the rotary plow after chisel plow1 pass followed by $0.02 \%$ precision land leveling slope required the lower irrigation water amount of $1550.05 \mathrm{~m}^{3} / \mathrm{fed}$. The rotary plow as minimum tillage, after chisel plow 1 pass and after chisel plow 2 passes saved the total irrigation water amount by 12,18 and 15\%, comparing with that required using the control treatment. It may be explained that the rotary plow creates fine soil particles that impede the infiltration process. Also, the precision land leveling of 0.010 .02 and $0.03 \%$ slope saved the total irrigation water amount by 28,36 and $32 \%$ from that was required using the traditional land leveling. It is due to the high accuracy of precision land leveling which decreases the water irrigation losses by deep-percolation, evaporation and run-off.

Rice straw application saved the total irrigation water amount by about $8 \%$ from that was required in case of the bereaved of rice straw application. This finding is illustrated that rice straw incorporation increases the soil moisture accumulation, resulting in the increase of soil water holding capacity, soil hydraulic conductivity and water retention.

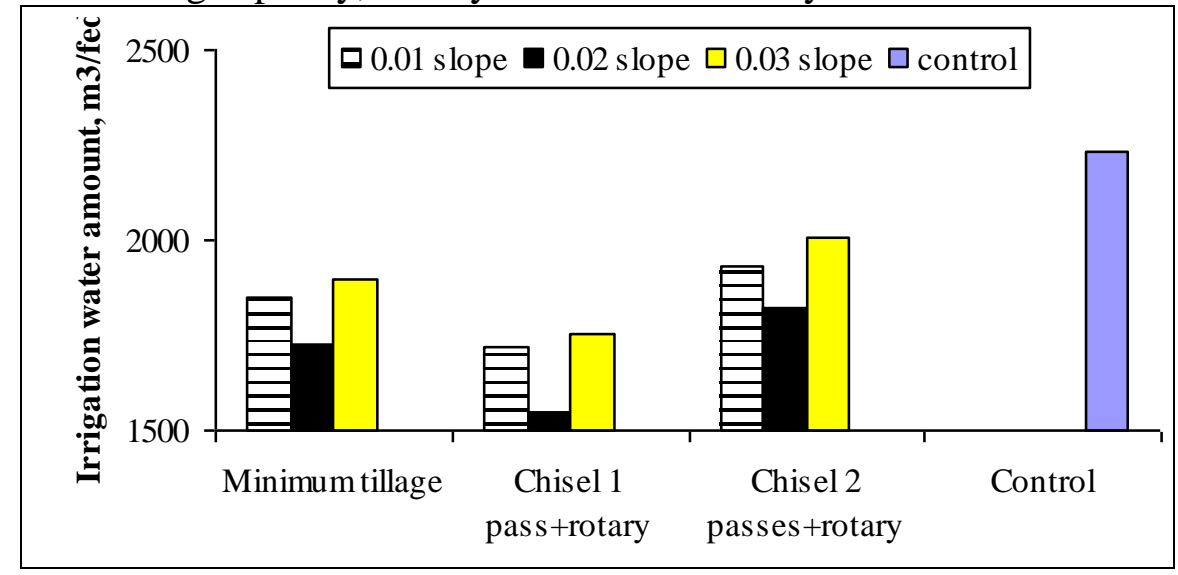

Fig. (8): Effect of rotary plow on applied irrigation water amount under different precision land leveling slope levels.

\section{Land Leveling Accuracy:}

Figure (9) reveals that using rotary plow after chisel plow1 pass followed by the precision land leveling of $0.01,0.02$ and $0.03 \%$ slope levels recorded the lower average level for the total spot readings values of 3.15 , 3.14 and $3.22 \mathrm{~m}$ with a standard deviation of $\pm 0.2386, \pm 0.1285$ and \pm 
0.2646 , respectively. It is due to the lower values of the difference between the highest and the lowest spots of $0.20,0.20$ and $0.40 \mathrm{~m}$ which were recorded using the rotary plow after chisel plow 1 pass at the previous land leveling slope levels with the same respect. While, using rotary plow after chisel plow 2 passes followed by the precision land leveling of $0.01,0.02$ and $0.03 \%$ slope levels accomplished the higher average level for the total spot readings values of 3.33, 3.20 and3.22 m with a standard deviation of $\pm 0.3470, \pm 0.2796$ and \pm 0.3351 , respectively. It is due to the higher values of the difference between the highest and the lowest spots of $1.10,0.80$ and $1.80 \mathrm{~m}$ at the previous land leveling slope levels with the same respect.

This finding may be explained that the rotary plow after chisel plow1 pass creates a proper disturbed surface which lowers the soil curette. In addition, this proper seed bed facilitates both the application and removal of soil water for irrigation and drainage. These practices can result in high efficiency of irrigation water application, uniform distribution of irrigation water and elimination of tail water. The irrigation water penetrated more rapidly in this proper seedbed than in other cases.

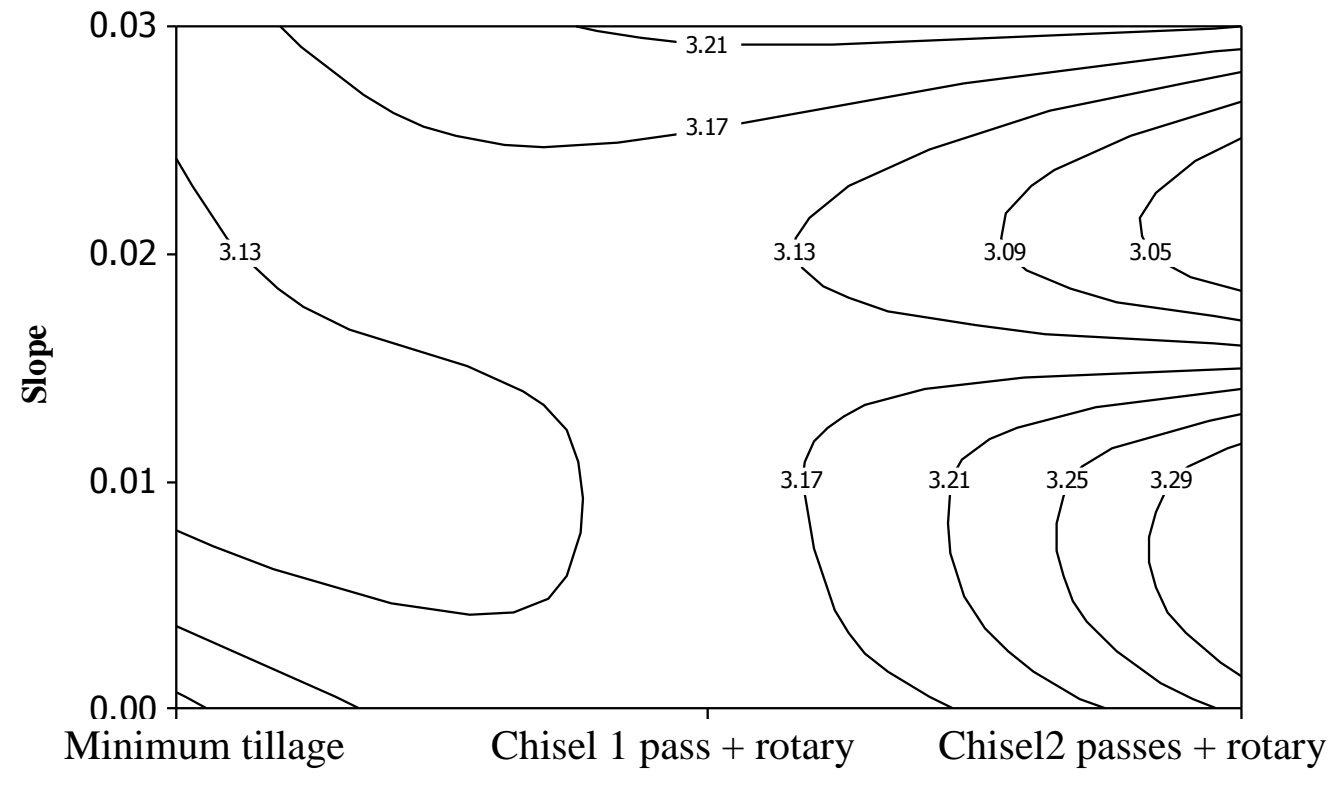

Tillage methods

Fig. (9): Schematic diagram of the experimental field grid survey at harvest. 
When application of water continued the soil water content become greater than other cases. The higher infiltration of water to depth appeared to be mainly due to the greater continuity of channels in soil which are not disturbed by either the intensive tillage or minimum tillage.

\section{Faba Bean seed Yield:}

Figure (10) demonstrates that the higher faba bean seed yield of 1.42 ton/fed was obtained using rotary plow after chisel plow1 pass followed by precision land leveling of $0.02 \%$ slope. The figure indicates that using the rotary plow as minimum tillage, after chisel plow1 pass and after chisel plow2 passes increased faba bean seed yield by 5,8 and $03 \%$ from that was obtained using the control treatment, respectively. While, the precision land leveling of $0.01,0.02$ and $0.03 \%$ slope, increased faba bean seed yield by 19,25 and $22 \%$ from that was recorded using the traditional leveling, respectively. This finding may be illustrated that the rotary plow and the precision land leveling improves the soil conditions, resulting in the release of more soil nutrients to uptake by faba bean plants. Meanwhile, rice straw application increased faba bean seed yield by about 9\% from that was yielded using the bereaved of rice straw application. This result is explained that rice straw decomposition leads to the increase of nutrients solubility and nutrient availability to the plants that enhance plant growth and development.

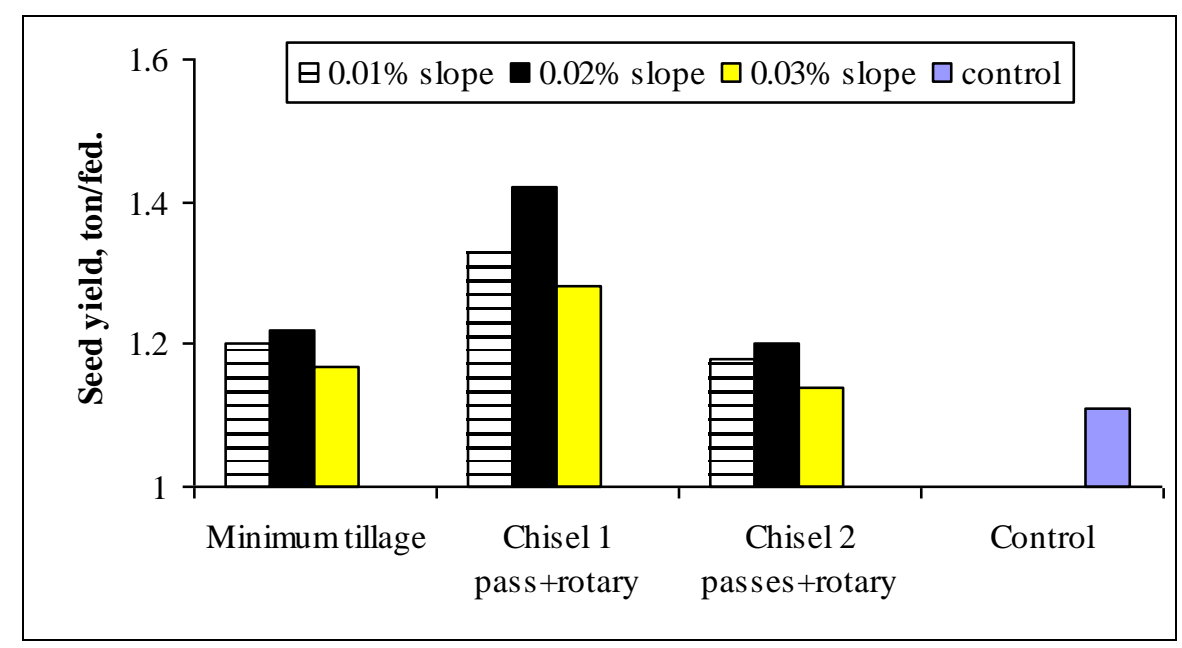

Fig. (10: Effect of rotary plow on faba bean seed yield under different precision land leveling slope levels. 
The analysis of variance test indicates that there is a highly significant difference in faba bean seed yield due to the rotary plowing the precision land leveling. The L.S.D. test at 0.05 level shows that the rotary plow after chisel plow1 pass followed by the precision land leveling slope of $0.02 \%$ achieved the highest faba bean seed yield among the other treatments. The regression and correlation analysis reveals that faba bean seed yield (y) correlated positively with the precision land leveling slope $(\mathrm{x})$ as follows:

Minimum tillage:

$\mathrm{y}=0.035 \mathrm{x}^{2}+0.125 \mathrm{x}+1.41$

$\left(\mathrm{R}^{2}=1\right)$

Rotary plow after chisel plow1 pass:

$\mathrm{y}=0.025 \mathrm{x}^{2}+0.105 \mathrm{x}+1.39$

$\left(\mathrm{R}^{2}=1\right)$

Rotary plow after chisel plow 2 passes:

$\mathrm{y}=0.140 \mathrm{x}^{2}-0.840 \mathrm{x}+1.40$

$\left(\mathrm{R}^{2}=1\right)$

\section{Water Use Efficiency:}

Figure (11) reveals that the higher water use efficiency value of 098 $\mathrm{kg} / \mathrm{m}^{3}$ was obtained using rotary plow after chisel plow 1 pass followed by $0.02 \%$ precision land leveling slope. Using rotary plow as a minimum tillage, after chisel plow1 pass and after chisel plow 2 passes increased the water use efficiency by 23,44 and $35 \%$ from that was recorded using the control treatment, respectively.

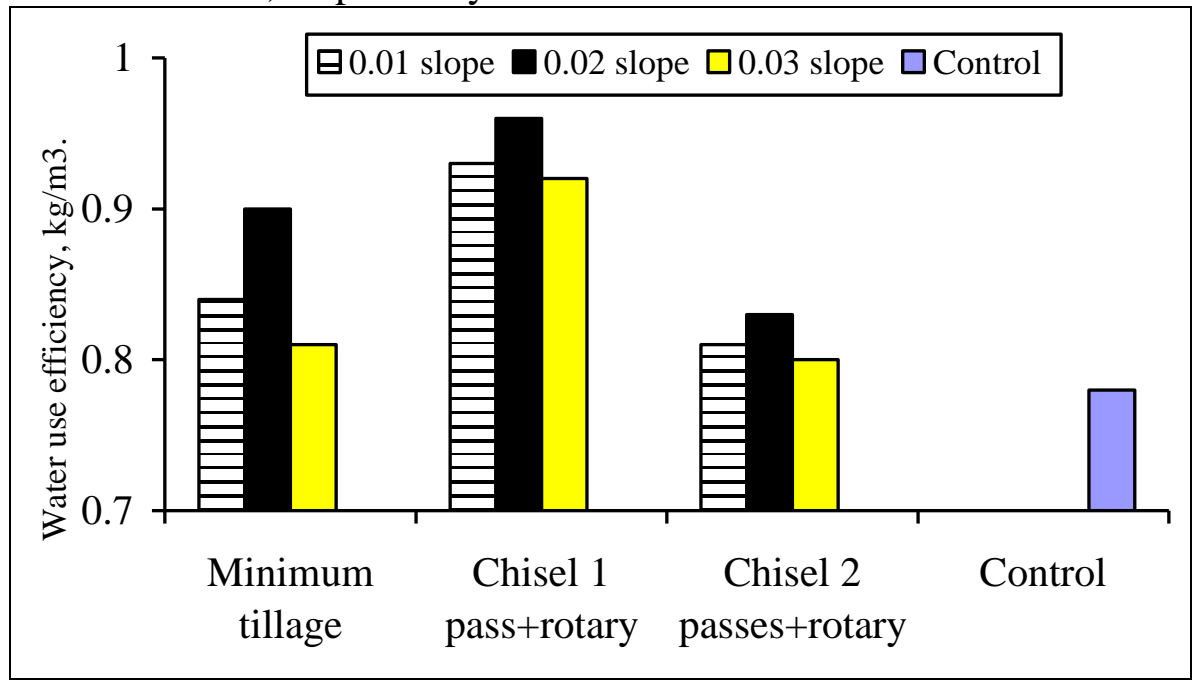

Fig. (11): Effect of rotary plow on faba bean water use efficiency under different precision land leveling slope levels. 
Also, the precision land leveling of $0.01,0.02$ and $0.03 \%$ slope, increased the water use efficiency by 64,100 and $98 \%$ from that was obtained using the traditional levelling, respectively. While, rice straw application increased the water use efficiency by $30 \%$, comparing with the bereaved of rice straw application.

\section{CONCLUSION}

The rotary plow after chisel plow 1 pass followed by $0.02 \%$ precision land leveling slope under rice straw application improved the soil characteristics, saved the total applied irrigation water amount, conserved significantly the soil topography and produced higher faba bean seed yield, comparing with the traditional practice. So, It is recommended to apply the rotary and the precision land leveling under rice straw application.

\section{REFERENCES}

Abd El-Aziz, F.I. (2008). Effect of biological and mineral fertilization on yield and quality of faba bean (Vicia faba L.) in Northern state. M.Sc. (Envir.) Thesis, (Council of Bio Sci., Advanced Tech. and Environment. Academy of Sci. Sudan.

Abd El-Hameed, M.T.; T. Horiuchi and O. Shiya (2004). Composting of rice straw with oilseed rape cake and poultry manure and its effects on faba bean (Vicia faba L.) growth and soil properties. Bioresource Tech., 93 (2): 189-193.

Abd EI-Galil, H.S. (2007). Effect of using rotary plow on soil physical properties and barley yield under rainfall conditions. Misr J. Agric. Eng., 24 (4): 666-687.

AbouAmer, A.I.; A.F. Hassan and M.A. Abd EI Wahab (2014). Effect of mineral fertilization and plant density on faba bean (Vicia faba) production in Siwa Oasis. Alex. J. Agric. Res. 59 (1): 19-26.

Ali, Laila K. (2011). Astudy of some methods of waste management of rice through its impact on soil physical properties, N, P and $\mathrm{K}$ contents in maize yield and water use efficiency under different tillage systems. Australian J. of Basic and Applied Sci., 5 (5): 1017 1034. 
ASAE standard: S296.4 (1992). Cubes, Pellet, and crumbles-definitions and methods for determining density, durability and moisture content: 384 .

Bahnas, O.T. and M.Y. Bondok (2010). Effect of precision land leveling on faba bean response to compost application.Misr J. Agric. Eng., 27 (2): 465-481.

Bescansa, P.; M.J. Imaz; I. Virto; A. Enrique and W.B. Hoogmoed (2006). Soil water retention as affected by tillage and residue management in semi-arid Spain. Soil and Tillage Res. 87: 19-27.

Doorenbos, J. and W.O. Prutt (1977). Guidline of predicting crop water requirements. Irrigation and drainage paperno 24.FAO.

El-Gendy, A.M.; M.A. El-Adl; H.N. Abd El-Maheed and E.M. Moohamed (2001). Management of pressurized irrigated faba bean in sandy soils. Misr J. Agric. Eng., 18 (1): 29-44.

El-Gendy, A.M.; M.A. Baiomy; M.M. Abdelhamed and Sahar,A. Mosa (2009). Design and fabrication of a simplified mechanical handling system of rice straw baling operation.To reduce environment pollution. Misr J. Agric. Eng., 26 (2): 676-685.

El-Khatib, S.I.; N.M. El-Bialee; Ilham I. El-Khatib and A.M. ElBialee (2014). Effect of laser leveling, water quantities and rhizobium inoculation on fixing $\mathrm{N} 2$ efficiency with faba bean. Agriculture and Biology J. of North America, 5 (2): 87-96.

El-Serafy, Z.M. and A.M. El-Ghamry (2006). Methods of soil and water analysis (Practices), Soils Dept., Faculty of Agric., Mansoura Univ., 253 pp.

FAO (1979). Irrigation and drainge. Paper No. 33. Rome. Italy.

Garcia, I. (1978). Soil-Water Engineering.Laboratory Manual.Dept. of Agric. and Chemical Eng., Colorado State Univ., 4th Collins, Colorado, USA.

Hegaba, A.S.A.; Maha , M.T.B. Fayedb; M.A. Hamadab and M.A.A. Abdrabboa (2014). Irrigation requirements of faba bean in North 
Delta of Egypt in relation to planting dates. Annals of Agric. Sci., 59 (2): 185-193.

Israelson, O.W. and V.E. Hansen (1962). Irrigation Principles and Practices.3rd Ed. John Willey and Sons. Inc., New York, 265 pp.

James, L. G. (1988). Principles of farm irrigation system design. John Willey\&sons.Inc.,WashingMg State Univ., 73: 152-153 and 350351.

Ji, X.H.; J.M. Wu; H. Peng; L.H. Shi; Z.H. Zhang Z.B. Liu; F.X. Tian; L.J. Huo and J. Zhu (2012). The effect of rice straw incorporation into paddy soil on carbon sequestration and emissions in the double cropping rice system. J. Sci. Food Agric., 92: 10381045 .

Kepner, R.A.; R. Beiner and E.L. Barger (1982). Principles of farm machinery. $3^{\text {rd }}$ Ed., The AVI Pup. Com. Inc. 527 pp.

Khider, M.O. (2004). Development of a combined unit with a combine for utilization in field waste. M.Sc. thesis Agric. Mech. Dept. Faculty of Agric. Mansoura Univ.

Lentz, R.D. and D.L. Bjorneberg (2003). Polyacrylamide and straw residue effects on irrigation furrow erosion and infiltration. J. Soil Water Conserv., 58: 312-319.

Mc Clung, J.A.; S. Shepley; M. Ismail and M.N. Seif El-Yazal (1985). Mechanical and economical study of land leveling in Middle Egypt.Ag. Mech. Proj. Paper work No. 21.Ministry of Agricultural and Land Reclamation.

Ministry of Agriculture and Land Reclamation (2005). Faba bean planting. Central Administration for Agric. Extension. Pamphlet No. 929 (In Arabic).

Ministry ofAgricultural and Land Reclamation (2013). Economic affairs sector. Bulletin of The Agric. Statistics. Part (1). Winter crops, 2011-2012: 27-29. (In Arabic) 
Rusu, T.; P.I. Moraru; I. Bogdan; A.I. Pop and M.L. Sopterean (2011). Effect of soil tillage system upon the soil properties, weed control, quality and quantity yield in some arable crops. World Academy of Sci., Eng. and Tech. 59.

Samiha, A. Ouda; M.A. Shreif and R. Abou El-Enin (2010). Increasing water productivity of faba bean grown under deficit irrigation at Middle Egypt. $14^{\text {th }}$ Int. Water Tech. Conf., Cairo, Egypt: $345-355$.

Savci, S. (2012). Investigation of effect of chemical fertilizers on environment. APCBEE Procedia, 1: 287-292.

\section{الملخص العربي - المبي}

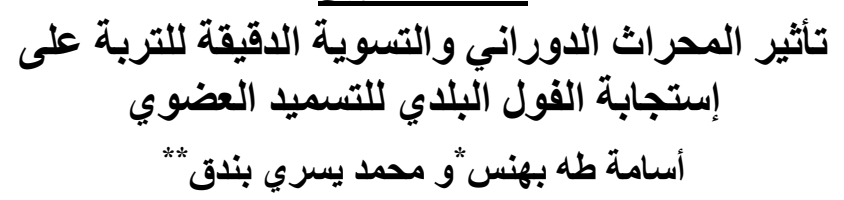

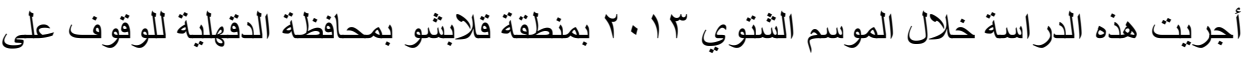

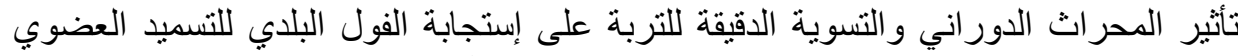

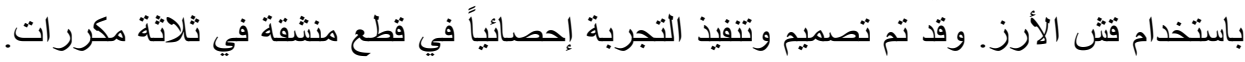

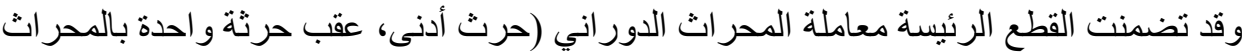

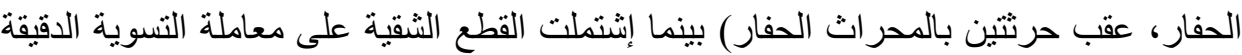

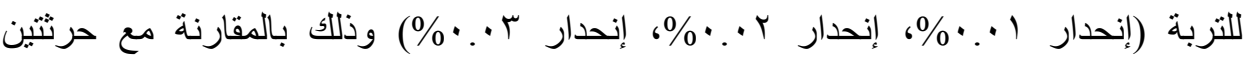
بالمحر اث الحفار ثم التسوية بالقصابية الهيدروليكية وبدون التسميد العضوي.

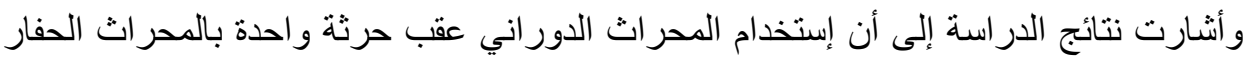

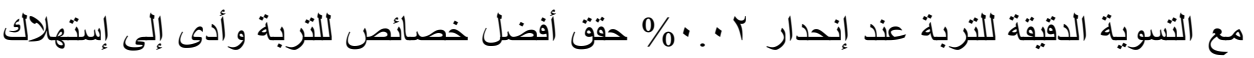

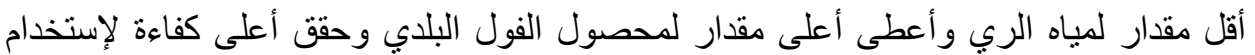

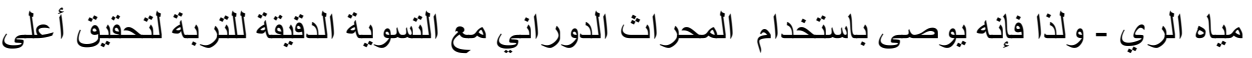
استفادة من الأسمدة العضوية لزيادة النتاج محصول الفول الفول البلدي.

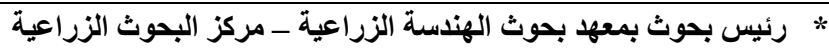
* * رئيس بحوث متفرغ بمعهل بحوث الهندسة الزراعية، مركز البحوث لزئة لزراعية. 